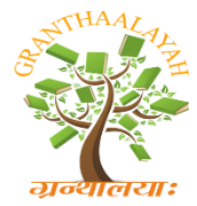

\author{
INTERNATIONAL JOURNAL OF RESEARCH - \\ GRANTHAALAYAH \\ A knowledge Repository
}

Science

\title{
CHROMITE DEPOSITS OF PAKISTAN: A SHORT REVIEW
}

\author{
Syed Tallataf Hussain Shah ${ }^{* 1}$, Mohsin Tariq ${ }^{1}$, Nangyal Ghani Khan ${ }^{1}$, Faizan-ur-Rehman \\ Qaiser ${ }^{2}$, Arsalan Iftikhar ${ }^{1}$, Ammar Farid ${ }^{1}$, Shah Naseer ${ }^{1}$ \\ ${ }^{* 1}$ Department of Earth Sciences, Comsats University Islamabad-Abbottabad Campus, Pakistan
}

\begin{abstract}
Chromite is an important source for the manufacturing of stainless steel, nichrome, paint, and chemicals industries and has wide industrial utilization. In Pakistan, the chromite deposits are mostly associated with the ophiolitic sequence resulting as an outpouring of molten material in the fractured zones of the Indian plate and the Neo-Tethys Ocean through the Cretaceous era. The discovery and documentation of chromite in Pakistan is traveling back to 1960s, but unfortunately, most of the reports are lacking authentication in reserve estimation and grading. If the modern and proper geophysical and geochemical analysis is performed to the reported area, then there are more bright chances of acquiring the more authenticate reservoir estimation, its distribution in the prospect zone and chemical composition per metric ton. The current article is an effort towards making a composite record of all the published/unpublished reports and articles regarding the chromite discovery, estimation, and extraction in Pakistan.
\end{abstract}

Keywords: Chromite Deposits; Pakistan.

Cite This Article: Syed Tallataf Hussain Shah, Mohsin Tariq, Nangyal Ghani Khan, Faizan-urRehman Qaiser, Arsalan Iftikhar, Ammar Farid, and Shah Naseer. (2019). "CHROMITE DEPOSITS OF PAKISTAN: A SHORT REVIEW."International Journal of Research Granthaalayah, 7(7), 70-78.https://doi.org/10.29121/granthaalayah.v7.i7.2019.718.

\section{Introduction}

Chromite is a spinel group mineral with the general chemical formula ( $\mathrm{Fe}, \mathrm{Mg}, \mathrm{Al}) \mathrm{Cr} 2 \mathrm{O} 4$. It is the main source for the extraction of chromium metal mainly used for the manufacturing of stainless steel, chemicals and has wide industrial usage. Chromite is mostly associated with ultramafic rocks and ophiolite sequences. Chromite deposits associated with ophiolite sequence termed as Alpine type and chromite deposits of Pakistan are the alpine type. In Pakistan chromite is mostly found in ophiolitic rocks near convergent margins [1] Figure 1.

Pakistan is bestowed with numerous economic mineral ores and chromite is one of them. The chromite mineral has economic significance in nichrome, paint industry, stainless steel, and refractory lining. Chromite which is a source of chromium is hosted in mafic and ultramafic rocks like harzburgite, pyroxenite, and dunite associated with ophiolites and their derivatives as part of 
the oceanic crust [2, 3]. Chromite deposits are classified into two classes as podiform and stratiform (Bushveld) deposits. Stratiform deposits occur as a sheet-like an accumulation of chromite in layered ultramafic and mafic rocks. These deposits are in the form of a funnel shape, flat or tabular to igneous complexes hosting chromite deposit [4]. The podiform chromite is found in ophiolite sequence with associated gabbros, sheeted dykes, mafic cumulates, and tectonics [4, 5]. These chromite deposits are found in irregular shapes, such as pod or lensoidal bodies and often in disseminated form. The chromite has magmatic origin formed by any of the following processes:

1) Formed by gravitational settling and fractional distillation of peridotite mantle.

2) Podiform chromite has been interpreted as a cumulate filling of a magma conduit inside the residual mantle.

3) It is also suggested that such deposits forms as a result of rock/melt or melt/melt interaction (magma-mingling).

4) By separation and settling of an immiscible chrome-rich melt.

In Pakistan, Chromite deposits are associated with ophiolite sequence resulted by the outpouring of molten material in the fractured zones of the Indian plate and Neo-Tethys ocean in Cretaceous time. In northern Pakistan, the ultramafic complexes are Dargai (Shahkot-Qila) and ShanglaMingora. The magmatic arc complexes of Indus suture zone includes Jijal complex, Sapat complex and Chilas complex of the Cretaceous age [6]. Chromite deposits in Balochistan are located at Bela ophiolites, Muslimbagh-Zhob, and Waziristan Ophiolites [7].

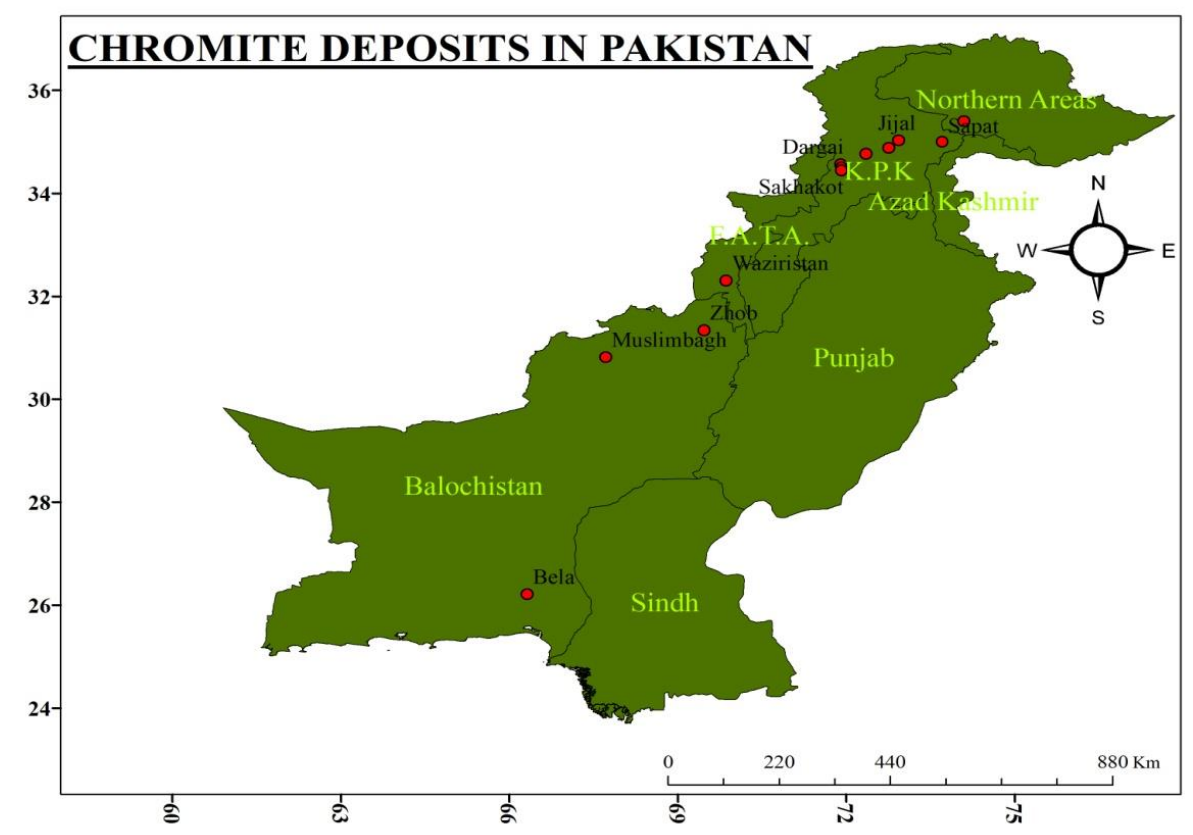

Figure 1: Location map of reported chromite deposits of Pakistan

\section{Geological Setting}

The Indian plate is separated from Gondwanaland, traveled 5000km northward before colliding with the Eurasian plate, resulting in the closure of Neo-Tethys Ocean to the North and opening of Indian Ocean in the South. This continent-continent collision of the Indian and Eurasian plates 
forms the great Himalayan mountain belt $[8,9]$. As far as the Indian plate is concerned which is subducting under the Eurasian plate along its Northern edge, resulting in the generation of a sequence of North-South dipping thrusts faults. The shortening of the crust generated numerous thrust and fold belts $[10,11]$. The collision of the continents resulted in the formation of deep and steep faults along the frontal part of Tethys terrain along which extensive ophiolites and melanges are abducted. This tectonized melange zone has been labeled as Indus Suture Zone (ISZ). The Indus Suture Zone can be traced EW continuously in Northern Pakistan through Kohistan Region till Lhasa region of the Southern Tibet $[12,13]$. In the North West, ISZ is linked with the transcurrent Chaman Fault [14]. To the south of the Indus Suture Zone, the axial zone of tightly folded Cretaceous sediments, pillow lava and large bodies of ophiolites (Bela, Muslimbagh, Zhob, and Waziristan) are present. Ophiolitic thrust belt arrays from near Karachi, through Lasbela, Zhob, and to North till Waziristan and Kurram Agency. The Bela ophiolitic thrust belt is largely composed of a thick and imbricated sequence of Mesozoic to Neogene rocks [15].

Chromite is generally found in the magmatic rocks; the main host rocks are serpentine peridotite, harzburgite, and cumulate dunite[16]. Large economic deposits of chromite are generally found in stratiform complexes while a relatively small proportion is present in pod-like or tabular lenses, or in irregular masses. It occurs mostly along the Indus Suture Zone (i.e. Northern Pakistan). The Sapat mafic-ultramafic complex of Kohistan may also contain some of the chromite deposits. Besham-Jijal chromite is located near the Jijal (Kohistan District) on the Karakoram highway. Several dozen chromite pods and lenses have been reported in ultramafic rocks in the northwestern part of the Jijal complex. Important deposits of chromite are locating near Jijal, Shungial, Kokial, Taghtai, Gabar, Mani Dara, Khairabad, Jag, Tangai, Chinari, Serai, Lomoto, and Kot[17]. Main localities of Chromites are Chilas, Besham-Jijal Kohistan, Harichand-Sakhakot-Qila west of Dargai, Kot-Pranghar (Mohmand), Bucha (Mohmand), Boya (Waziristan), Muslimbagh, Zhob, Bunap, and Rayo Ras Koh, Wad, Sonaro, and Ornach. These ophiolites contain lenticular or disseminated bodies of chromite [15].

These deposits are situated in different tectonic environments. The Zhob, Wad, and Boya deposits occur in ophiolites which are part of the oceanic crust and upper mantle and were abducted by the sedimentary sequence during Paleocene. Chromite bearing ophiolites in the Dargai and Pranghar areas in northern Pakistan are thrust slices of abducted masses present along suture zone in between Kohistan magmatic arc and Indo-Pakistan Gondwanian Domain [15]. The Jijal ultramafic rocks are regarded as deep-seated island arc cumulates, while the chromite-bearing Chilas Complex is related to the Kohistan arc and may be formed during intra-arc rifting in the starting phases of the development of a back-arc-basin [6].

The Chilas complex is a very large mafic intrusion, dominantly comprised of gabbro-norite with minor intrusive bodies of ultramafic rocks including dunites, harzburgites, troctolites, hornblende gabbros, pyroxenites, and anorthosites [18]. Jijal complex comprises of ultramafic rocks and garnet-granulites. These ultramafics are comprised of dunite, peridotite, diopsidite, websterite and chromitite[19]. Dargai ophiolite complex is comprised of harzburgite, dunite, gabbro with few layers of serpentinite [20]. According to Jan, et al. [3], a complete normal ophiolitic sequence is present in Boya (Waziristan area), but at different localities, various members of this sequence were observed as ultramafic rocks, gabbros, sheeted dikes, pillow lavas, paleogranites. Ultramafic rocks include harzburgite, dunite, and pyroxenite. Zhob area is marked as the largest and best- 
known occurrence of ophiolites in Pakistan and is documented as Zhob valley ophiolite belt. The Lasbela-Khuzdar region contains the largest ophiolitic complex in Pakistan. The ophiolites include fragments and blocks of peridotite, dunite, minor pyroxenite, serpentinite, diabase, gabbro and lava flows. These ophiolites contain lenticular or disseminated bodies of chromite [20].

\section{Chromite Deposits in Pakistan}

Chromite is an oxide mineral containing Iron, Oxygen, and chromium [( $\mathrm{Fe}, \mathrm{Mg}, \mathrm{Al}) \mathrm{Cr} 2 \mathrm{O} 4]$. It occurs in mafic and ultramafic rocks deposits which are formed by masses of igneous rocks such as norite called stratiform deposit while the podiform deposits contain metamorphic rocks. Due to the weathering of laterite soil i.e. developed over peridotite and chromite-bearing rocks, chromite may also find in the beach sands. In Pakistan Chromite Deposits are located in Chilas Complex, Sapat Complex, Jijal Complex, Shangle-Mingora, Malakand Agency-Sakhakot (Dargai), Waziristan, Zhob valley Igneous Complex, Bela and Muslimbagh.

\subsection{Chilas Complex}

Chilas Complex is closely allied with Kohistan-Island-Arc sequence of the Northwestern Himalayas [18]. Chilas Complex is chiefly composed of dunite, pyroxenite, olivine gabbro, anorthosite, peridotite, gabbronorite and amphibolite dikes [1, 18]. According to Jan [21], the complex can be more associated with the stratiform rather than the concentric or alpine complexes. Jan [21] also reported the thin layers of chromite with the $26 \%$ of $\mathrm{Cr} 2 \mathrm{O} 3,26 \%$ of A12 O3, $37 \%$ of $\mathrm{FeO}$ and $9 \%$ of $\mathrm{MgO}[1]$.

\subsection{Sapat Complex}

Sapat Complex is mainly located in Sapat Valley and it extends for approximately $15 \mathrm{~km}$ and acquires thickness of approximately $2 \mathrm{~km}$ [22]. Within the $100 \mathrm{~m}$ chromite layers of the Sapat complex, scattered grains and small lumps $(\sim 14-10 \mathrm{~cm})$ of chromite and dunites are reported by Arif and Jan [6]. This complex is not economically rich and the chromite layers are thin and associated with silicates. The largest mass of chromitite (a boulder) reported by Jan, et al. [22] is about the size of $25 \mathrm{~cm}$ across.

\subsection{Jijal Complex}

Jijal Complex is located near the Indus Suture Zone i.e. Northern edge of Indian Plate and the southern portion of Kohistan Island Arc. Jijal Complex includes granetgranulites and ultramafic rocks. According to Jan and Windley [23], the ultramafics include dunite, peridotite, diopsidite, chromitite and vebsterite. In the northwestern part of the Jijal complex, the chromite in ultramafic rocks is reported in the form of pods and lenses [24, 25]. The southern portion of Kohistan Island Arc involves a 10x4 km slab of chromite-bearing pyroxenite, dunite, and peridotite [6] in layered form. These rocks are formed by the high-temperature and pressure fractional crystallization. The documented SDA estimates of ore reserves are $0.6 \mathrm{mt}$ with $40-50 \%$ of $\mathrm{Cr} 2 \mathrm{O} 3$ and $12-18 \%$ of Fe2O3, while the Cr: Fe ranges from 2.8:1 to 3.6:1 [1]. The important deposit locations are Jijal, Kokial, Shungial, Gabbar, Mani Dera, Taghtai, Jag, Khairabad, Tangai, Chinari, Serai, Lomoto, and $\operatorname{Kot}[24,25]$. 


\subsection{Shangla-Mingora}

The Mingora ophiolitic mélange of the Indus Suture Mélange Group (ISMG) involves the ophiolitic lithologies of the Shangla and adjoining parts of the Swat valley [6]. The region consists of isolated chromite. The field, textural, and chemical features of the segregated chromite largely resembles podiform chromite deposits [26]. It comprises on ultramafic rocks having pyroxenite, dunite, harzburgites, and lherzolite with Chromium-rich chromitite.

\subsection{Malakand Agency- Sakhakot (Dargai)}

The chromite deposits in this area extend from Sakhakot to Qila in the east and to Malakand Agency in the west [27]. It comprises of ultramafic rocks containing $80 \%$ of harzburgite and $20 \%$ of dunite; while the mafic deposits consist of gabbro with minor layers of serpentine. The ultramafic tectonites are comprised of $<10 \%$ of dunite and $>90 \%$ of the harzburgite $[1,28]$.

The region contains low grade metamorphic (pelitic, calcareous and carbonaceous) rocks and ultramafites (harzburgite and peridotite dominantly) and dunite pyroxenite veins are also present in a minor amount. The chromite ore deposits, unlike most podiform deposits, develop nodular texture in many outcrops with invariable rounded out lines. Nodules are spherical to oval and occur in clusters [27]. The region may be in irregular form and spindles found set-in fine-grained chromite. These chromite ore deposit have alpine characteristics close to Jijal Complex (ultramafic) i.e. characteristic feature of podiform chrome ore deposits which helps distinguish them from stratiform deposits [29].

Rossman and Abbas [28] reported that the chromite in the upper part of the complex is found in $3-4.5 \mathrm{~m}$ thick and $2 \mathrm{~km}$ laterally extending layers, irregular massive bodies of $<1 \mathrm{~m} 2$ thickness in the western part while podiform, massive and irregular along the sharp contacts such as Hiru Shah deposit [1]. Main deposits are located at BarjoKanri, Hiru Shah, LandiKand, Qila and Badasar. The Dargai chromite is rich in iron and low in chromite-oxide i.e. low $\mathrm{Cr}$ : Fe ratio, however, some of the ore contains $45 \% \mathrm{Cr} 2 \mathrm{O} 3$. The SDA ore reserves are estimated as $\sim 0.67 \mathrm{mt}$ [1].

\subsection{Waziristan Ophiolite}

Boya chromite in the northern Waziristan is found the ophiolite rocks situated in the west of Razmak, formed by over-thrusting of Jurassic over Cretaceous sediments [1]. Waziristan ophiolites are distributed to an area of around $2000 \mathrm{~km} 2$ of the Northern Waziristan [30]. After Bela and Muslim-Bagh ophiolites, the Waziristan ophiolite is largest in Pakistan. The rocks in this region are folded and faulted having copper mineralization with small chromite lenses in the ultramafic and gabbro-anorthosite rocks. Dyke swarms, volcanic breccias, lava flows, and pillow lavas were also included [1]. The lenses of chromite are $0.5-1 \mathrm{~m}$ thick and $6 \mathrm{~m}$ long. The chromite in Waziristan is reported at Mami Rogha, Sherkai, Tut Nari and MadarAglad[1, 31].

\subsection{Bela Ophiolites}

The area is part of Alpine Himalayan orogenic belt that contains mafic and ultramafic composition. Mafic rocks include gabbro, diorite granite, and quartz. Ultramafic rocks act as hosts for $\mathrm{Cr}, \mathrm{Ni}$, 
$\mathrm{Cu}$ and PGE mineralization [32] and comprise on wehrlite, harzburgite, clinopyroxenite, dunite, and serpentinized products. The Bela ophiolite belt runs along the western boundary of the Indian Plate from Bela to the coast of the Arabian Sea and west of Karachi [6]. This region dominantly contains ophiolitic and continental clasts.

\subsection{Muslim Bagh \& Zhob Chromite}

The Muslim Bagh chromite is found in scattered ophiolites of Zhob River valley while Zhob Chromite is found near the Zhob town as a small deposit. The exposure of larger outcrops is near Muslimbagh and Khanozai areas. It comprises of two main parts: Jang Tor Ghar Massif (JTGM) and Saplai Tor Ghar Massif (STGM) Bilgrami[33]. Between the Chaman transform fault to the west and the Indian shield to the east, the valley extends in NEE-SWW direction for around $250 \mathrm{~km}$ [6]. The region displays ultramafic tectonites, mafic and ultramafic cumulates along with Greenschist facies, Amphibolite facies, Mylonitic peridotite, Garnet Amphibolite facies, pillow lavas, dike complex, dolerite dike swarm and dunite, harzburgite, gabbros, etc. The massive ore bodies surrounded by grape-shot ores, banded ores, cigar-shaped ore bodies and banded deposits of disseminated ores. The irregular dike like ore bodies referred to as Aluminous chromite is having the estimated reserves as 100-1500 ton with thin wiggly $100 \mathrm{~m}$ of extension [1]. Economically the valley chromite divided into following two divisions.

1) Veins, bands, and Serpentine with minor amounts

2) Serpentinizeddunite rich.

These are mostly low-grade ores [34]. Chromites in Muslim Bagh may be completely opaque and translucent. Jang Tor Ghar ore is metallurgical grade while the Naweoba\&Zizha are refractory grade chromite [1,35]. According to Ahmad and Bilgrami [35], the Naweoba\&Zizha ores contain $36.7-46.5 \%$ of $\mathrm{Cr} 2 \mathrm{O} 3$ with $\mathrm{Cr}$ : Fe ratio of 2.9:1 [1]. The mineralogy \& petrology of the Muslim Bagh igneous complex reported by Bilgrami [36] revealed the presence of $\mathrm{Cu}, \mathrm{Ni}, \mathrm{Co}, \mathrm{V}$ and $\mathrm{Cr}$ in the rocks.

\subsection{Bunap \& Rayo Ras Koh Chromite}

The Bunap and Rayo Ras Koh chromite are located 30km NW of the Kharan Kalat town. The chromite is disseminated in dunites within $3 \mathrm{~km}$ belt of lenticular bodies. Jones [37] reported seven deposits with reserves of 355 tons near the Rayo Nai while nine small-sized deposits with a total reserve of 9664 tons near Bunap.

\subsection{Wad, Sonaro, Ornach Chromite}

The largest ophiolitic complex of Pakistan covering $320 \mathrm{~km}$ is located near the Khuzdar-Lasbela district. The mélange contains Jurassic to Cretaceous sediments and huge blocks of ophiolites. The opholites contains the fregments and blocks of peridotite, minor pyroxene, serpentinite, dunite, diabase, gabbro and lava flows. The Sonaro block shows the complete sequence of pillow lavas and sediments at the top while ultramafic tectonites at the base with a total extension of over 116 sq. km [1]. The ultramafic rocks of Teru, Yasin and Pakora areas of Shyok Suture are reported with the composition of $\mathrm{Ni}, \mathrm{Cr}$, and $\mathrm{Co}$. 


\section{Discussion}

Pakistan has abundant chromite deposits located in both northern and western parts of the Indus Suture Zone, Besham, Jijal, Chilas, Kohistan, Kot-Pranghar (Mohmand), Boya (Waziristan) Harichand, Sakhakot-Qila west of Tehsil Dargai, Bucha (Mohmand), and in ophiolite complexes of Baluchistan as Bela and Muslimbagh-Zhob ophiolites in form of disseminated or lenticular bodies of chromites[15]. At present mining of chromite is taking place both in KPK and Baluchistan which started in 1903 in Khanozai area near Muslimbagh. Chilas complex consists of stratiform chromites rather than alpine (podiform) deposits mainly in gabbro norites, anorthosites, granulite diorite facies and some ultramafic like dunite, peridotite with occasional amphibolites. The composition of deposits shows $\mathrm{Al} 2 \mathrm{O} 3$ 26\%, $\mathrm{FeO} 37 \%, \mathrm{MgO} 9 \%$ and $\mathrm{Cr} 2 \mathrm{O} 326 \%$ content. The Jijal complex consists of chromites hosting in peridotite, chromitite, vebsterite and diopsidite[23]. The estimated reserves of ore are $0.6 \mathrm{mt}$ with Fe2 $\mathrm{O} 3$ 12-18\% and $\mathrm{Cr} 2 \mathrm{O} 3$ 40-50\%, [18] occur near Jijal, Kokial, Manidara, Gabar, Tangai, Jag, Serai, Kot, and Lomoto[1]. The Dargai chromite of Malakand district occurs as laterally extensive layers (2 Km long,3-4 meter thick) in the upper portion of Qila complex and massive, podiform and irregular deposits of the western part of the complex (Hiru Shah Complex) [28]. The reserve is high in iron and low in chromite and estimated about $0.67 \mathrm{mt}$ and found economically viable to process 20,000 tons of ore to get 8,000 tons of chromitessulphate, 300 tons of sodium sulphate and 1500 tons of sodium dichromate annually [18]. Mohmand agency chromites of Bucha, Kot-Pranghar area is found in the form of lenses, and dissemination in ultramafic rocks in melange zone near villages of AuroKhawar, Bucha, Yousaf Baba, and Parai. Boyachromites Waziristan is found in ophiolite sequence in the form of lenses, disseminated and segregated grains. lenses are $6 \mathrm{~m}$ long and 0.5-1 meter thick [17], and are reported from sherkai, TutNari, MamiRogha. Muslimbaghchromites (Qila Saifullah) are found in the typical sequence of mafic and ultramafic cumulates ultramafic tectonics and a dike complex mainly in two large bodies namely Jang tor gar and Saplai tor gar. Chromites occur in different forms and shapes like disseminated, banded ore and a dike like the body of 100-meter length with a total reserve of 100-1500 ton. These are metallurgical grade and refractory grade chromites[35]. Zhob area deposits show ore containing $\mathrm{Cr} 2 \mathrm{O} 336.7-46.5 \%$ and $\mathrm{Cr}$ : $\mathrm{Fe}$ ratio of 2.9:1. Khuzdar- Lasbela is largest ophiolite complex in Pakistan and containing blocks of peridotite, serpentine, gabbro, and dunite. These ophiolites host lensoidal or disseminated chromites bodies. Chromites deposits of Kharan exist as lenticular bodies in dunites. Seven deposits with reserves of 355 ton and 9 deposits of 9.664 ton have been reported, this area is exhaustedly mined but still, mining is going on showing more deposits. Therefore, the study should be carried out to get more out of these deposits and through geophysical surveys these deposits should be marked and mapped for further exploration.

\section{Conclusions and Remarks}

The present study is an effort to describe the mafic and ultramafic complexes positioned along the adjoining zone of the Indian plate and the masses deriving from Eurasia looks as if have developed by changing different environment that host chromite deposits. Chilas complex is the foremost result of Kohistan magmatic arc developed during upward movement resistance to mantle diapir. Jijal and Sapat Complexes located at the northern side of Indian plate which is the southern part of Kohistan arc cumulates to arc magmatism. Muslim Bagh ophiolite has metamorphic sole rocks consist of foliated peridotite, dunite, inverted metamorphic sequence, serpentinised, and 
greenschist facies. Chromite deposits of Waziristan, Bela, Shangla-Mingora, Muslimbagh, and Dargai suggest mostly transitional tectonic setting between mid-oceanic and island arc, such as peripheral basins and supra-subduction zones. Since chromite is susceptible to magnetic and electrical surveys, it is therefore suggested that if proper geophysical techniques are utilized then imaging the lateral as well as a vertical extension of the chromite deposits in the reported areas is possible. Similarly using the modern and more sophisticated geochemistry techniques can provide a better estimation of mineral composition and percentage.

\section{References}

[1] M. S. Malkani and Z. Mahmood, "Mineral Resources of Pakistan: A Review," Geological Survey of Pakistan, Record, vol. 128, pp. 1-90, 2016.

[2] Z. Ahmed, "Stratigraphic and textural variations in the chromite composition of the ophiolitic SakhakotQila Complex, Pakistan," Economic Geology, vol. 79, pp. 1334-1359, 1984.

[3] M. Q. Jan, B. F. Windley, and A. Khan, "The Waziristan ophiolite, Pakistan; general geology and chemistry of chromite and associated phases," Economic Geology, vol. 80, pp. 294-306, 1985.

[4] J. Duke, "Ore deposit models 7. Magmatic segregation deposits of chromite," Geoscience Canada, vol. 10, 1983.

[5] J. S. Dickey, "A hypothesis of origin for podiform chromite deposits," in Chromium: its Physicochemical Behavior and Petrologic Significance, ed: Elsevier, 1976, pp. 1061-1074.

[6] M. Arif and M. Q. Jan, "Petrotectonic significance of the chemistry of chromite in the ultramafic-mafic complexes of Pakistan," Journal of Asian Earth Sciences, vol. 27, pp. 628-646, 2006.

[7] M. Jan, B. Windley, and A. Khan, The Waziristan ophiolite, Pakistan; general geology and chemistry of chromite and associated phases vol. 80, 1985.

[8] S. T. H. Shah, J. Zhao, J. Zhao, U. Baral, and N. G. Khan, "Indian-Eurasian collision, structur Himalayan syntaxis along Pamir-Tajikistan- A short review," International Research Journal of Earth Sciences, vol. 6, pp. 11-19, 2018.

[9] S. T. H. Shah, J. Zhao, Q. Xiao, Z. I. Bhatti, N. G. Khan, H. Zhang, et al., "Electrical resistivity structures and tectonic implications of Main Karakorum Thrust (MKT) in the western Himalayas: NNE Pakistan," Physics of the Earth and Planetary Interiors, vol. 279, pp. 57-66, 2018.

[10] C. T. Klootwijk, J. S. Gee, J. W. Peirce, G. M. Smith, and P. L. McFadden, "An early India-Asia contact: paleomagnetic constraints from Ninetyeast ridge, ODP Leg 121," Geology, vol. 20, pp. 395-398, 1992.

[11] Z. I. Bhatti, J. Zhao, N. G. Khan, and S. T. H. Shah, "Structure of crust and upper mantle beneath NW Himalayas, Pamir and Hindukush by multi-scale double-difference seismic tomography," Physics of the Earth and Planetary Interiors, vol. 281, pp. 92-102, 2018.

[12] S. T. H. Shah, J. Zhao, J. Zhao, B. Upendra, N. G. Khan, F. Z. I. Bhatti, et al., "Structural and tectonic deformation of the Tibetan plateau since Cretaceous: An upshot of Indian-Eurasian collision," International Research Journal of Earth Sciences, vol. 6, pp. 9-18, 2018.

[13] J. Zhao, S. T. H. Shah, H. Zhang, X. Zhang, C. Yao, Y. Li, et al., "Density and magnetic intensity of the crust and uppermost mantle across the northern margin of the Tibetan Plateau," Physics of the Earth and Planetary Interiors, vol. 265, pp. 15-22, 2017.

[14] B. Kummel, "Stratigraphy and paleontology of the Permian-Triassic boundary beds, Salt Range and trans-Indus ranges, West Pakistan," Stratigraphic Boundary Problems: Permian and Triassic of West Pakistan, vol. 4, pp. 1-110, 1970.

[15] M. S. Malkani, S. Tariq, F. Buzdar, G. Khan, and J. Faiz, "Mineral Resources of Pakistan-an update,"Lasbela University Journal of Science \& Technology, vol. 5, pp. 90-114, 2016.

[16] S. Roberts, "Ophiolitic chromitite formation; a marginal basin phenomenon?" Economic Geology, vol. 83, pp. 1034-1036, 1988.

[17] M. S. Malkani, Z. Mahmood, M. I. Alyani, and M. Siraj, "Mineral Resources of Khyber Pakhtunkhwa and FATA, Pakistan," Geological Survey of Pakistan, Information Release, vol. 996, pp. 1-61, 2017.

[18] M. A. Khan, "The Chilas Mafic-Ultramafic Igneous Complex; The root of the Kohistan Island Arc in the Himalaya of northern Pakistan," Tectonics of the western Himalayas, vol. 232, p. 75, 1989. 
[19] M. Q. Jan and R. Howie, "The mineralogy and geochemistry of the metamorphosed basic and ultrabasic rocks of the Jijal complex, Kohistan, NW Pakistan," Journal of Petrology, vol. 22, pp. 85-126, 1981.

[20] A. Kazmi and S. Abbas, "Metallogeny and mineral deposits of Pakistan," Islamabad, Pakistan: Orient Petroleum, 2001.

[21] M. Q. Jan, "The Chilas stratiform complex: field and mineralogical aspects," Geol. Bull. Univ. Peshawar, vol. 17, pp. 153-169, 1984.

[22] M. Q. Jan, M. A. Khan, and M. S. Qazi, "The Sapat mafic-ultramafic complex, Kohistan arc, North Pakistan," Geological Society, London, Special Publications, vol. 74, pp. 113-121, 1993.

[23] M. Q. Jan and B. F. Windley, "Chromian spinel-silicate chemistry in ultramafic rocks of the Jijal complex, Northwest Pakistan," Journal of Petrology, vol. 31, pp. 667-715, 1990.

[24] M. Ashraf and M. Chaudhry, "Magnetite deposits of lower Kohistan District, Hazara Division, Pakistan," Metallurgist, vol. 1, pp. 15-23, 1980.

[25] M. Ashraf, M. Chaudhry, and S. Hussain, "General geology and economic significance of the Lahor granite and rocks of the southern ophiolite belt in Allai-Kohistan area," Geological Bulletin, University of Peshawar, vol. 13, pp. 207-213, 1980.

[26] M. Arif and M. Q. Jan, "Chemistry of chromite and associated phases from the Shangla ultramafic body in the Indus suture zone of Pakistan," Geological Society, London, Special Publications, vol. 74, pp. 101-112, 1993.

[27] Z. Ahmed, "Chromite from Sakhakot-Qila area, Malakand Agency, Pakistan," Mineralogical Magazine, vol. 42, pp. 155-157, 1978.

[28] D. Rossman and S. Abbas, "Geology and Economic potential for chromite in the ultramafic rock complex near Dargai, Peshawar division," Geol. Surv. Pak., Unpubl. Rep, 1970.

[29] Z. Ahmed, "Porphyritic-nodular, nodular, and orbicular chrome ores from the Sakhakot-Qila Complex, Pakistan, and their chemical variations," Mineralogical Magazine, vol. 45, pp. 167-178, 1982.

[30] M. I. Kakar, K. Mahmood, A. C. Kerr, and M. Khan, "Petrology of the mantle rocks from the Muslim Bagh Ophiolite, Balochistan, Pakistan," Journal of Himalayan Earth Science, vol. 46, 2013.

[31] M. A. Khan and W. Ahmad, "Report on SDA mineral activities in NWFP, SDA, Directorate of Minerals. 46p," (undated).

[32] E. Bashir, S. Naseem, T. Akhtar, and K. Shireen, "Characteristics of ultramafic rocks and associated magnesite deposits, Nal Area, Khuzdar, Balochistan, Pakistan," Journal of Geology and Mining Research, vol. 1, pp. 034-041, 2009.

[33] M. I. Kakar, M. Khan, K. Mahmood, and A. C. Kerr, "Facies and distribution of metamorphic rocks beneath the Muslim Bagh ophiolite,(NW Pakistan): tectonic implications," Journal of Himalayan Earth Sciences, vol. 47, p. 115, 2014.

[34] P. Park, "Chemical composition of the Zhob valley chromites, West Pakistan," THE AMERICAN MINERALOGIST, vol. 45, 1960.

[35] Z. Ahmad and S. Bilgrami, "Chromite deposits and ophiolites of Pakistan," Chrom. ore, Van Norstrand Reinhold Co. NY, pp. 239-269, 1987.

[36] S. A. Bilgrami, "Distribution of $\mathrm{Cu}, \mathrm{Ni}, \mathrm{Co}, \mathrm{V}$, and $\mathrm{Cr}$ in Rocks of the Hindubagh Igneous Complex, Zhob Valley, West Pakistan," Geological Society of America Bulletin, vol. 72, pp. 1729-1738, 1961.

[37] A. Jones, "Reconnaissance Geology of part of West Pakistan, a Columbo Plan cooperative project," Hunting Survey Corporation, Government of Canada, Toronto, 1961.

\footnotetext{
*Corresponding author.

E-mail address: tallataf@ cuiatd.edu.pk
} 